\title{
Access to Justice for Victims of Dating Violence: Gender Perspective
}

\author{
Trianah Sofiani ${ }^{1}$ \\ ${ }^{1}$ Faculty of Sharia, Institut Agama Islam \\ Negeri Pekalongan, Pekalongan - \\ Indonesia
}

CorrespondingAuthor:Trianah Sofiani, email:triana.sofiani@iainpekalongan.aci, Jl. Pahlawan Km. 5, Bojong, Pekalongan, Jawa Tengah 51156

\begin{abstract}
This gender perspective of qualitative research explores the shape, causes, impact of dating violence; and access to justice for dating violence victims. Data collection using observation, interviews, questionnaires, and literary studies. The analysis uses an interactive model. The results showed that the shape of dating violence, i.e: verbal-emotional, physical, sexual, and economic. The main causes of dating violence are patriarchal culture and a lack of understanding of gender, thus causing gender inequality, parenting gender-biased, women stereotype, and the absence of regulation about dating violence. Dating violence affects not only victims but also the perpetrators. The dating violence victims have not gained access to justice, because the legal system, which includes the substance, structure, and legal culture, is still gender-biased and patriarchal. This condition is confirmed by the fact that the community and victims do not know, understand, and be aware of their rights to justice. Therefore, we needed efforts to understand gender and dating violence, including access to justice for victims, through student activity in and out of the campus. Law making about eliminating dating violence in the future (ius constituendum) must be political agenda for the government and legislative.
\end{abstract}

Keywords: gender; dating violence; access to justice; patriarchy

Abstrak: Penelitian kualitatif perspektif gender ini mengeksplorasi bentuk, penyebab, dampak dari kekerasan dalam pacaran; dan akses keadilan bagi korban kekerasan dalam pacaran. Pengumpulan data menggunakan observasi, wawancara, angket, dan studi pustaka. Analisis menggunakan model interaktif. Hasil penelitian menunjukkan bahwa, bentuk kekerasan dalam pacaran yaitu: verbal-emosional, fisik, seksual, dan ekonomi. Penyebab utama kekerasan dalam pacaran adalah budaya patriarkhis dan kurangnya pemahaman tentang gender sehingga menyebabkan ketidaksetaraan gender; pola asuh bias gender; stereotip perempuan, dan tidak adanya regulasi tentang kekerasan dalam pacaran. Kekerasan dalam Pacaran, tidak hanya menimpa korban tetapi juga pelakunya. Para korban kekerasan dalam pacaran belum mendapatkan akses keadilan, karena sistem hukum yang meliputi substansi, struktur, dan budaya hukum masih bias gender dan patriarkhis. Kondisi ini diperkuat dengan masih minimnya pengetahuan, pemahaman, dan kesadaran masyarakat tentang hak mereka atas keadilan. Oleh karena itu, diperlukan upaya untuk memberikan pemahaman tentang gender dan kekerasan dalam pacaran, termasuk akses keadilan bagi korban, melalui kegiatan kemahasiswaan di dalam dan di luar kampus. Pembentukan undang-undang tentang penghapusan 
kekerasan dalam pacaran di masa depan (ius constituendum) harus juga menjadi agenda politik bagi pemerintah dan legislatif.

Kata Kunci: gender; kekerasan dalam pacaran; akses memperoleh keadilan; patriarkhis

\section{A. Introduction}

The violence of women in the personal sphere affects those who are married and those who are still dating. The 2018 Annual Records of the National Commission on Violence against Women showed an increase in the number of cases of dating violence where data from the Indonesia Office of Women's Empowerment, Child Protection and Family Planning (DP3AKB) ${ }^{1}$ are 703 cases, 323 cases of Woman Crisis Center, 322 cases on Integrated Service Center for the Empowerment of Women and Children (P2TP2A), 296 cases on Women and Children Service Unit (UPPA) ${ }^{3}$ and 216 cases on the District Court (PN). ${ }^{4}$ It means there were 1860 cases of dating violence in 2018, but only 216 cases reached the court process, or $10 \%$ of the dating violence figures reported. ${ }^{5}$ On the 2019 Annual Records of the National Commission on Violence against Women, dating violence cases have increased to 2,073 cases from a total of 8604 cases of violence against in the private/personal sphere. ${ }^{6}$

In Central Java, based on data from the Legal Resources Center for Gender Justice and Human Rights (LRC-KJHAM) ${ }^{7}$ from January to February, in 2017, case reports were recorded in LRC-KJHAM that there were 58 cases of violence against women and 11.02 percent or 19 cases were dating violence. ${ }^{8}$ In July

\footnotetext{
1 Dinas Pemberdayaan Perempuan, Perlindungan Anak dan Keluarga Berencana.

2Pusat Pelayanan Terpadu Pemberdayaan Perempuan dan Anak.

3 Unit Pelayanan Perempuan dan Anak.

${ }^{4}$ Pengadilan Negeri.
}

${ }^{5}$ Komnas Perempuan, “CATAHU 2019: Korban Bersuara, Data Berbicara, Sahkan RUU Penghapusan Kekerasan Seksual sebagai Wujud Komitmen Negara. Catatan Kekerasan terhadap Perempuan Tahun 2018," Komnas Perempuan, 2019, https://komnasperempuan.go.id/catatantahunan-detail/catahu-2019-korban-bersuara-data-berbicara-sahkan-ruu-penghapusankekerasan-seksual-sebagai-wujud-komitmen-negara-catatan-kekerasan-terhadap-perempuantahun-2018.

${ }^{6}$ Komnas Perempuan, "Lembar Fakta dan Poin Kunci Catatan Tahunan Komnas Perempuan Tahun 2019," Komnas Perempuan, 2019, https://komnasperempuan.go.id/catatan-tahunandetail/lembar-fakta-dan-poin-kunci-catatan-tahunan-komnas-perempuan-tahun-2019.

${ }^{7}$ Legal Resource Center untuk Keadilan Jender dan Hak Asasi Manusia

${ }^{8}$ M. Nur Huda, "Kekerasan Seksual pada Perempuan di Jateng Terhitung Tinggi," Tribun Jateng, April 21, 2017, https://jateng.tribunnews.com/2017/04/21/kekerasan-seksual-padaperempuan-di-jateng-terhitung-tinggi. 
2019, the number of dating violence complaints in LRC-KJHAM was 10 cases. $^{9}$ According to Annual Records of National Commission on Violence against Women and LRC-KJHAM, victims of dating violence have an age range between 17-24 where sexual violence is the highest. ${ }^{10}$

This fact is increasingly interesting and relevant to be studied with the following arguments: 1 ) dating violence is a form of violence against women in the personal realm and violence against women is included in the category of gender-based violence; 2) dating relationship is a relationship that is free from legal protection (vacuum of norm), so that if violence occurs, the victim will face several obstacles in accessing justice; 3) most of the victims of dating violence are women. It happens because of the imbalance of gender relations constructed by patriarchal culture.

Several previous studies have shown a positive relationship between gender relations inequality and dating violence. According to Azmianis and Supradewi's research, men who have positive attitudes towards gender equality are less likely to do dating violence. On the other hand, men who have negative attitudes towards gender equality are most likely to do dating violence. ${ }^{11}$ Yatdianto's research on UNIKA Semarang students shows that the more positive gender prejudice is, the lower the possibility of dating violence. On the contrary, the more negative the gender prejudice is, the higher the possibility of dating violence. ${ }^{12}$ Wulandari's research shows a positive relationship between masculinity and dating violence behavior, where the aspect of power over women contributes the most to dating violence. ${ }^{13}$ This study can be interpreted that, if men have a positive attitude towards gender equality and

9Wisnu Adhi N., "Kekerasan terhadap Perempuan di Jateng Masih Tinggi," Antara News, April 21, 2017, https://www.antaranews.com/berita/625333/kekerasan-terhadap-perempuan-dijateng-masih-tinggi.

${ }^{10}$ Komnas Perempuan, "Siaran Pers Catatan Tahunan (CATAHU) Komnas Perempuan 2019: Hentikan Impunitas Pelaku Kekerasan Seksual dan Wujudkan Pemulihan yang Komprehensif bagi Korban," Komnas Perempuan, 2019, https://komnasperempuan.go.id/siaran-pers-detail/siaranpers-catatan-tahunan-catahu-komnas-perempuan-2019.

${ }^{11}$ Azmiani Azmiani and Ratna Supradewi, "Hubungan Sikap Laki-Laki terhadap Kesetaraan Gender dengan Kekerasan dalam Pacaran," Jurnal Psikologi Proyeksi 10, no. 1 (2015): 49-60, https://doi.org/10.30659/jp.10.1.49-60.

12Yatdianto Ariel, "Kekerasan dalam Pacaran Ditinjau dari Prasangka Gender" (UNIKA Soegijapranata, Semarang, 2015).

13Pingky Wulandari, "Hubungan antara Maskulinitas dengan Kekerasan dalam Pacaran pada Remaja Laki-Laki” (Universitas Mercu Buana Yogyakarta, 2019). 
prejudice, it can minimize dating violence and masculinity contributing to high dating violence rates.

The 2018 IAIN Pekalongan Islamic Faculty Legal Aid Institute survey of on hundred college students throughout the Pekalongan Residency showed that as many as forty-nine female students experienced verbal-emotional violence, five experienced physical violence. Violence, eight people experienced economic violence, and twenty-eight people experienced sexual violence. Even four people had been pregnant, one person had an abortion, one person married another person, and two people married the man who impregnated her (her boyfriend). ${ }^{14}$

Gender inequality constructed by the patriarchal social order has manifested and created a naive awareness for the victims to think it is normal for their boyfriend to commit violence. The existence of a legal vacuum further weakens the position of women in gaining access to legal justice in dating relationships. It is the root of the problem, so that the dating violence case is like the tip of the iceberg because many go unreported.

This gender perspective qualitative research explores the forms, causes, and impacts of dating violence behavior; and access to justice for victims of dating violence. The research location is at the Colleges in the ex-Residency Pekalongan. Key informants were female students with the following criteria: ages between nine-teen to twenty-one years; Islam; dating for at least two years. Supporting informants are boyfriends, parents, and friends. The data collection techniques being used are observation, interviews, questionnaires, and literary studies. The analysis technique being used is an interactive model.

\section{B. Tracing the Forms, Causes, and Effects of Violence Behavior in Dating Relationship}

Dating relationships are dyadic interactions to carry out joint activities to continue the relationship after agreement about their relationship status. ${ }^{15} \mathrm{~A}$ dating relationship is a relationship between two people who have emotional attachments based on certain feelings in the hearts of each party. Dating

${ }^{14}$ LBH Fakultas Syariah IAIN Pekalongan, “Laporan Hasil Survey,” 2018, 39.

${ }_{15}$ Murray A. Straus, "Prevalence of Violence Against Dating Partners by Male and Female University Students Worldwide," Violence Against Women 10, no. 7 (2004): 790-811, https://doi.org/10.1177/1077801204265552. 
violence is an act based on gender differences that results in physical, sexual, or psychological suffering, including threats of certain actions, coercion, or deprivation of liberty, in public or private life. ${ }^{16}$ According to the Office on Violence Against Women of the U.S. Department of Justice, "Dating violence is controlling, abusive, and aggressive behavior in a romantic relationship. It occurs in both heterosexual and homosexual relationships and can include verbal, emotional, physical, or sexual abuse, or a combination of these".17 According to Krahe, dating violence is an act or threat of violence by someone in a dating relationship. ${ }^{18}$ Based on these definitions, the indicators of dating violence behavior are: 1) there is a dating relationship; 2) there is an act done physically, sexually, verbally, psychologically; and 3) there are perpetrators and victims.

\section{Forms and Acts of Dating Violence}

Dating violence is included in the category of violence against women in the private sphere. Article 1 of the 1993 UN Declaration on the Elimination of Violence against Women, defines violence against women, as "Any act of gender-based violence that results in, or is likely to result in, physical, sexual or psychological harm or suffering to women, including threats of such acts, coercion or arbitrary deprivation of liberty, whether occurring in public or in private life". The article can be interpreted that violence against women can take physical, sexual, psychological, coercive, and arbitrary forms.

\section{Verbal-emotional Abuse}

Verbal violence is violence against feelings by using harsh words, slanderous words, words that threaten, insult, or exaggerate the mistakes of others. ${ }^{19}$ According to Brewer, emotional violence in dating relationships is an emotional state that is deliberately created to control their partner. For

16Dyah Prita Wardani and Yossy Setyanawati, "Tinjauan Viktimologi dan Perlindungan Hukum Korban Kekerasan dalam Pacaran," Serambi Hukum 8, no. 2 (2015).

${ }^{17}$ Francine Lavoie, Line Robitaille, and Martine Hébert, "Teen Dating Relationships and Aggression," Violence Against Women 6, no. 1 (2000): 6-36, https://doi.org/10.1177/ 10778010022181688.

${ }^{18}$ B. Krahe, Perilaku Agresif (Yogyakarta: Pustaka Pelajar, 2005); Winda Rizwanti Utami, "Hubungan Antara Harga Diri dengan Perilaku Kekerasan dalam Pacaran" (Universitas Muhammadiyah Malang, 2016), 3.

${ }^{19}$ Annora Mentari Putri and Agus Santoso, "Persepsi Orang Tua tentang Kekerasan Verbal pada Anak," Jurnal Keperawatan Diponegoro 1, no. 1 (2012): 22-29. 
example, teasing, excessive suspicion, always blaming your boyfriend/girlfriend, restraining, and so on. ${ }^{20}$ The difference between verbal and emotional violence is verbal violence is in the form of speech (words), while emotional violence consists of words and actions. So verbal abuse is part of emotional abuse.

Verbal and emotional violence can be categorized as psychological violence if it causes psychological consequences for the victim. According to Article 7 of the Constitution of the Republic of Indonesia Number 23 of 2004 regarding the Elimination of Domestic Violence, what is meant by psychological violence is an act that causes fear, loss of self-confidence, loss of ability to act, feeling of helplessness, and severe psychological suffering in someone. This article defines psychological violence in the context of the consequences caused to the victim, not on the act committed by the perpetrator of the violence.

Based on the results of the interview, it shows that the verbal-emotional violence that occurs in the dating relationship of students at the Pekalongan Residency, among others: 1) ridiculing the partner with the words bodoh (stupid), goblok (idiot), lemot (slow-witted), gatel, cerewet (fussy) and cangkemu, cocotmu (Javanese), thus offending and hurting the partner; 2) checking the contents of the partner's cellphone and if they don't recognize the number on the cellphone, will ask in detail who the person is, why they called, and so on; 3) getting angry with their partner, if they don't immediately pick up calls, and/or don't immediately answer WhatsApp (chat message), by saying hurtful words over the phone and/or keeping quiet with a sullen expression when they meet, or other behaviors; 4) not keeping promises repeatedly, causing the partner to be restless and waiting; 5) monopolizing partner's time, by always being alone and spending time with his girlfriend anywhere from morning tonight. The local term refers to "lengket kayak perangko" (sticky like a stamp) or "kayak bakul gemblong" (as gemblong seller);21 6) Like to accuse and blame their partner (blaming). These actions are in the form of accusing the partner of cheating on them, accusing the partner of lying, accusing the partner of being the cause of late to class, and other accusations; 7) having an affair or two-

\footnotetext{
${ }^{20}$ Gayle Brewer and Loren Abell, "Machiavellianism, Relationship Satisfaction, and Romantic Relationship Quality," Europe's Journal of Psychology 13, no. 3 (2017): 491-502, https://doi.org/ 10.5964/ejop.v13i3.1217.

${ }^{21}$ Gemblong or juadah is a food symbol that husband and wife always peddle.
} 
timing. That happens that if their boyfriends cheated on them, most of the victims forgave them because they still loved them; 8) threatening, this action is done to control and dominate the partner to comply by looking for the partner's weakness. According to the interview results, the forms of threats, namely: want to leave or break off the relationship; want to spread the disgrace of a partner through online media; and others; 9) possessive towards their partner. The act of limiting the partner's space for movement, and always controlling the partner by interrogating, for example: where are you now? what are you doing there? What's your business? with whom? boy or girl? How many people? or why do you not reply to my text? etc., so that the partner feels uncomfortable; 10) forcing to do something that the partner doesn't want. For example: being forced to lie to parents, being forced to do actions that are not liked, and so on; 11) the act of stalking, which is always following, tailing, and a series of activities that interfere with privacy and limit the partner's daily activities, so they feel pressured and uncomfortable. ${ }^{22}$

\section{Sexual Violence}

Sexual violence is forced sexual activity or contact based on coercion and threats. For example, hugging, kissing, touching, groping, even forcing sexual relations under threat. More extreme behavior manipulates a partner to have sex by giving drugs so their partner is willing to have sexual intercourse.

The research results showed that one person admitted that she often had sexual relations with her boyfriend, three people admitted that they had had sexual relations with their boyfriends; six people admitted to having been kissed and touched on their body and sexual organs, fourteen people claimed to have been and/or often been kissed, two people admitted that they only held hands and have their cheeks touched. Several students who were interviewed showed that they actually did not want and often regretted having sexual intercourse, kissing, and being touched by their boyfriends, but could not refuse because they were threatened with leaving or breaking up. "My boyfriend was angry and threatened to leave me if I refused to do it (sexual act), even though I often feel scared, afraid of getting pregnant, afraid of sins, just fear....... ${ }^{\prime 23}$ said Diana.

${ }^{22}$ Private interviews from 21 July to 30 August 2019.

23Private interview on 29 July 2019. 
Ironically, when several students were interviewed, with the same tone, they said, "You're pretentious and not a real man if you have a girlfriend and didn't touch them." Some even said, "I'm proud to conquer girls .... There's even a friend of mine who hasn't done it but said he has .... As I said, they don't want to get called pretentious and not a man ...." This sentence turned out to have become a common conversation among students (male), even according to their statement, when hanging out with male friends, they often talk to each other about things that have been done with his girlfriend (kissing, groping, intimate acts) and others. ${ }^{24}$

When asked, did you force your girlfriend to do this (kissing, sex, groping, other sexual-related acts.)? Several students answered with the same tone, "No way, is there any girls nowadays who are forced? It's them who wanted it ...." One student named Rusdi, who likes to change girlfriends recounted proudly: "At first the girl was shy like a cat, pretending not to want, but gradually they're becoming addicted .... And provoking to be touched and kissed .... Girls ifyou coax, flatter, caress them .... Will be smitten and obedient .... Will be willing to do anything ..... If they got pregnant, usually it's because of lack of experience and information .... After all, you can anticipate it so they don't get pregnant .... There are birth control pills, condoms, a lot of ways .... I know my friends who often ask their girlfriends out and have experience, most of them usually do that (sexual intercourse)." When asked who friends who like to ask their girlfriends out (sexual intercourse) as he meant? "Only for private circles ...." Rusdi replied shortly. 25

Based on the above statements, it can be interpreted that, there are differences in views between students (men) and women regarding sexual relations and/or contact with their boyfriends, namely: for male students, sexual contact is pride, power, control, and egoism related to masculinity in him, on the other hand for female students, they do it as a form of affection, love, resignation, nrimo (acceptance) and fear of being left, fear of angering their partner, so even though they don't want and regret it, they still obeys what their boyfriend wants. This difference occurs because the social construction built-in society is based on patriarchal culture.

${ }^{24}$ Private interview on 9 August 2019.

25 Private interview on 9 August 2019. 


\section{Physical Abuse}

Physical violence is behavior that causes a partner to be physically injured, such as hitting, slapping, throwing objects, kicking, pushing, biting, scratching, banging, gripping the partner's body hard, forcing them to places that endanger the safety of the partner, and a series of other physical actions. The results showed that boyfriends rarely committed physical violence. Still, three people admitted that they had been slapped by their boyfriends because of jealousy, because they were caught cheating but did not want to admit it, resulting in quarrels and being slapped. According to the students (male) in dating relationships, there are rarely men who commit physical violence against their boyfriends, and if so they think it's casuistic. "The one who likes to hit girls are only drunk guys, I never heard of it and if there is that means it's an insane guy.... You're a guy and your opponent is a girl .... Embarrassing .... Instead, it's girls who like to hit us when she's angry and jealous... While crying ...." said, several students. $^{26}$

The word "embarrassing" in the expression is interesting to note. The meaning of "embarrassing" here does not have a positive connotation as an expression of affection, pity, or wanting to protect women, but on the contrary as an effort to show strength, pride, and masculinity as a male creature that is identical to macho, manly, mighty, and strong physically, so it is not appropriate to deal with women who are identified with being physically weak. Their high self-esteem as men makes them think it's worthy only when fighting against men and not women.

\section{Economic Violence}

Economic violence is any act or action that causes a partner to lose financially, for example, controlling income, not allowing partners to work, often borrowing money or other items without returning it, always asking to be treated, asking a partner to fulfill all his life needs (using or mloroti their partner), and so on. ${ }^{27}$ The research results showed that economic violence that often occurs, for example: being forced to pay when buying gasoline, paying

\footnotetext{
26Private interview on 21 July to 30 August 2019.

${ }^{27}$ Dewita Hayu Shinta and Oetari Cintya Bramanti, Kekerasan dalam Rumah Tangga: Reduksi Bentuk-Bentuk Kekerasan dalam Rumah Tangga dalam RUU KUHP, ed. Erasmus Cahyadi (Jakarta: LBH APIK dan Aliansi Nasional Reformasi KUHP, 2007).
} 
when eating, paying when watching movies, borrowing money from a partner but not returning it, borrowing an ATM card to take money. As stated by Indah: "I sometimes don't like having to pay continuously, but my boyfriend said that once he gets money, he will repay me .... But he never repays me .... My boyfriend also said, why are you being stingy with your boyfriend .... In the end, I gave in."28 Some female students said "How could you make girls pay, it should be the other way around...." but there are some who said, "If just once in a while because there's no other way, the most important thing is to not take advantage of girls...." there are even some who said "I instead take advantage of my boyfriend to buy all my needs. To date you have to have money, if the boy doesn't have money then don't date ...." When the cross-checks were carried out on the students, [the male students] said, "Girls are all gold digger, that's just their nature.... But it's not a problem, the most important thing is they're kind and obedient ...." there's also some who said "Not all girls are the gold digger, there are some who's understanding ...." and "They're already asking a lot before even becoming wives, what about later when they've become wives." ${ }^{29}$

The above statements can be interpreted as saying that women mostly perpetrate economic violence, but behind that, women do not realize that what their boyfriends do is a form of hidden control over the power and power of men over women.

In the explanation of the forms of violence as above, it can be stated that: 1) victims of dating violence are mostly women (female students); 2) forms of dating violence that often occur verbal-emotional violence and sexual violence, while physical and economic violence is casuist in nature; 3) the view that women who commit economic violence are a form of male power and power to control their partners in dating relationships; 4) the fact that women also commit physical violence (hitting) occurs because of the impact of violence perpetrated by their partners. The act of hitting by women (female students), has no significant impact on the partner because it only expresses feelings of sadness and disappointment; 5) between forms of violence with one another, inseparable, interrelated, and mutually supportive, becoming an inseparable circle, with the victim being a woman.

28Private interview on 25 July 2019.

${ }^{29}$ Private interview on 21 July to 30 August 2019. 
The new modus operandi found in cases of dating violence is through electronic media (cyber). For example, they were threatening to share inappropriate (sensual) photos on social media if they do not comply with the boyfriend's wishes during a fight, and if the woman asks to end the relationship. Ironically, the female students who were victims of the violence considered violence perpetrated by their boyfriends as something normal and a dynamic in the relationship. They also do not realize that what happened to them is a form of violence, even according to student $X$, who became pregnant out of wedlock and had an abortion, thinking what happened to him was his fault for loving his girlfriend so much.

\section{Causes of Violent Behavior in Dating}

Violent behavior in dating does not automatically arise because this behavior is caused by various conditions that are interrelated and supportive of one another.

\section{Patriarchal Culture}

The patriarchal culture is the main cause of dating violence behavior because patriarchy is a very legitimate tool to maintain asymmetrical relations between men and women. Patriarchy shapes the differences in behavior, status, and authority of men and women, becoming the gender hierarchy. Biological differences between men and women are considered to be the beginning of forming a patriarchal culture. Women possessing no muscles are believed to be the reason for putting women in a superior-inferior position; on the other hand, men are considered to have physically strong so that they are ordinate-superior compared to women..$^{30}$

According to radical feminist thinking, the roots of oppression against women occur because of the patriarchal system, and women's bodies are the main object of oppression by male power. ${ }^{31}$ Therefore, body and sexuality hold a very important essence, because the oppression of women begins with the domination of women's sexuality in the private sphere. The dominance of men

\footnotetext{
30Fakih Mansour, Analisis Gender dan Transformasi Sosial, 10th ed. (Yogyakarta: Pustaka Pelajar, 2013), 9.

${ }^{31}$ Mary Wollstonecraft, "Feminisme Liberal," in Feminist Thought: Pengantar Paling Komprehensif Kepada Aliran Utama Pemikiran Feminis, ed. Rosemarie Putnam Tong (Yogyakarta: Jalasutra, 1998), 68.
} 
in a patriarchal system causes violence to befall women, including violence in dating, which appears natural and "proper". ${ }^{32}$

This condition affects the perspective of students in the Pekalongan residency in dating relationships. "Men has to protect their girlfriends, have to be stronger than their girlfriends, have to be braver than their girlfriends, have to be able to guide their girlfriends, you're a future husband, future family iman, future household leader, you have to be tougher than your girlfriends ...."33 they said simultaneously. The phrase "Stronger, protect, leader, guiding, brave and tough" can be interpreted as male superiority. Superiority versus inferiority is what causes violence in dating.

\section{Parenting Patterns in a Gender-biased Family}

Boys ever since young age are raised with masculine parenting styles and girls are raised with feminine parenting styles. As stated by the parents of the perpetrators of violence who were interviewed, namely: "Boys must be strong, brave, must not be crybaby, and girls must be gentle, patient, nrimo (accepting), good at cooking, good at managing the house, that is their nature .... " Further: "Boys play with swords, cars, kites, soccer which fits boys and girls play cooking, dolls, and others .... If boys play cooking, they will turn out to be sissy later...."34 Parents educate boys in the belief that men cannot lose to women. This is expressed by the sentence "Ojo kalah ro cah wedok", "Mosok kalah ro cah wedok, isin ra" and "Ora ilok nek kalah ro cah wedok". This parenting style makes boys grow up as selfish, self-centered, arrogant, disrespectful of women and others.

According to psychoanalysis thinking, the series of experiences from childhood resulted not only in the way men see themselves as masculine and women see themselves as feminine but also in the way society views masculinity as better than femininity. ${ }^{35}$ Chorodow ${ }^{36}$ argues that the tendency of men's domination over women is rooted in the infant phase, in which girls and boys identify because of their mental and physical bonds with their mothers. As they

${ }^{32}$ Gadis Arivia, Filsafat BerperspektifFeminis (Jakarta: Yayasan Jurnal Perempuan, 2003), 152.

${ }^{33}$ Private interview on 21 July to 30 August 2019.

34 Private interview on 21 July to 30 August 2019.

${ }^{35}$ Rosemarie Putnam Tong, Feminist Thought: Pengantar paling Komprehensif kepada Arus Utama Pemikiran Feminis (Yogayakarta: Jalasutra, 1998), 190.

${ }^{36}$ Nancy Chodorow, The Reproduction of Mothering: Psychoanalysis and the Sociology of Gender (Berkeley \& Los Angeles: University of California Press, 1978). 
grow up, a woman loses her closeness and bond to her mother and replaces her with the father, then the opposite sex. This process does not have a big impact on women because they still have the mother's femininity and their relationship with the father. On the other hand, this process has a big impact for men because they have to suppress their identification with their mother to be like their father as a whole. This difference occurs because the woman's relationship with the father is additional, while the man's relationship with the father is a substitute relationship. Therefore, in social relationships, women prefer groups and are full of affection than men because their closeness to their mother continues; conversely, a man tends to feel imprisoned in his relationship with other people. $^{37}$

\section{Lack of Knowledge and Understanding of Gender}

The results of a survey of one students showed that $15 \%$ knew gender; $10 \%$ understand gender and $75 \%$ do not know and understand gender. They know that gender is the same as the concept of sex, where the functions and roles of men and women are considered natural, thus affecting relationships in dating.

\section{Inequality of Gender Relations in Dating Relationships}

The patriarchal culture and low understanding of gender are the causes of inequality in gender relations in dating relationships. The results showed that, in dating relationships, male students considered the woman who was their girlfriend as an "object" who could be treated as they please, including by violence.

As a radical feminist, MacKinnon emphasizes that inequality in gender relations is the root of the emergence of violence against women, including dating violence. Mac Kinnon calls it "Phallocentris, the world is still in the grasp of men". Kinnon argues, that in the power relationship where men have a more dominant role, higher status, and greater power than women, the relationship between the two will become unequal. This thought was emphasized by Gramsci that, when the patriarchal ideology became an ideology of hegemony, what happened was an unequal pattern of power relations between men and women and the root cause of violence occurred due to the imbalance of these relations. ${ }^{38}$

${ }^{37}$ Arivia, Filsafat BerperspektifFeminis, 230.

${ }^{38}$ Thomas R. Bates, "Gramsci and the Theory of Hegemony," Journal of the History of Ideas 36, no. 2 (April 1975): 351-66, https://doi.org/10.2307/2708933; Chantal Mouffe, "Hegemony and 


\section{Perspective on Women}

The patriarchal culture that manifests in perpetrators and victims, coupled with low gender knowledge and understanding, results in the viewpoint of women as weak and helpless creatures, with a series of stereotypes inherent in women. Non-physically, women are seen as a weak, fragile, crybaby, teasing, seductive, not independent and others, while from the physical side, women are identical to beautiful, white, slender, tall, sexy, voluptuous, big ass, big breasts, sharp nose, sexy lips, and others that cause male lust. The results of the interview showed: "Ifyou have a boyfriend, you have to be sexy and beautiful, so you don't embarrass your boyfriend when you're on a date." 39 The word "can be asked on a date" has become a concept that is often heard and/or commonly heard among men, it has even become a reference for men looking for a life partner. This means that the perspective of men in seeing women is only from the physical side, and women are goods and/or objects that can be exhibited physically or sexually by men, including young men who are still college students. Said perspective on women, is not only the belief of the male students but also the female students. The interview with one of the female students showed that she felt insecure and afraid of being abandoned by her boyfriend. She thought that she was not slim, even though she had a myriad of academic and non-academic achievements and was one of the activists on her campus.

\section{Low Knowledge and Understanding of Dating Violence}

The lack of knowledge and understanding of the forms of violence experienced by victims resulted in them not realizing that they had become victims of violence perpetrated by their boyfriends. They only know and understand that violence is identical to physical things, such as hitting, slapping, kicking, yanking, banging, killing, and physically related. In contrast, they think that other than physical violence is not violence. The lack of knowledge and understanding of female students and male students about dating violence has resulted in this violence continuing and growing, even leading to forced sexual intercourse, abortion, and various other actions that can threaten the lives of victims, most of whom are women.

Ideology in Gramsci," in Gramsci and Marxist Theory (RLE: Gramsci) (London: Routledge, 2014), 178214.

${ }^{39}$ Private interview on 21 July to 30 August 2019. 


\section{Less than Optimal Personality Development}

According to one female student, her boyfriend was very possessive, jealous, irritable, often angry, disrespectful, and even harsh. When traced, it turns out that the perpetrator was raised in an authoritarian family, often received insults, was underappreciated by parents, and always blamed, so that he grew and developed with a less than optimal personality. According to Skinner, behavior is a person's reaction to external stimuli. Behavior occurs through the process of a stimulus to the organism. Then the organism responds ${ }^{40}$ According to Aristotle and John Locke, human development begins from birth, where humans are born in an empty state like a wax table or wax paper (tabula rasa). Paper or candle tables will be filled and colorful, because of the family and community environment. Experience is very dominant in shaping human behavior because the experience will scratch or paint white wax paper, causing a diversity of behaviors. ${ }^{41}$

\section{Peer Influence}

Peers or peer groups have a big influence in contributing to a person's behavior, including violence in dating. Strong peer influence occurs because the relationship is more intense than with family. According to most (male) students, when they gather, what is interesting to talk about is a female student who is beautiful, light-skinned, sexy, has sexy lips, beautiful eyes, is easy to seduce, wants to be invited to go out, easy to deceive, easy to be flattered, gold digger, and so on. Male students also like to talk about things they have done to their girlfriends, for example: kissing, groping, having intimate relationships with their girlfriends, and so on. This affects other students, and if there is a student who does not like their peers' behavior, they will be eliminated, excluded, and/or go away from their peers. According to one female student: "My friends said you're outdated ifyou've never kissed before." ${ }^{42}$

\footnotetext{
${ }^{40}$ Bimo Walgito, Psikologi Umum (Yogyakarta: Andi Offset, 2003), 71-87; C. George Boeree, Personality Theories: Melacak Kepribadian Anda Bersama Psikolog Dunia, ed. Abdul Qodir Shaleh, trans. Inyiak Ridwan Muzir (Prismasophie, 2017), 257.

${ }^{41}$ Sumadi Suryabrata, Psikologi Kepribadian (Jakarta: RajaGrafindo Persada, 2012), 7.

${ }^{42}$ Private interview on 21 July to 30 August 2019
} 


\section{Media Influence}

Electronic media is the most powerful tool in influencing student behavior. Various shows of violence, infidelity, sexual acts and others can trigger dating violence behavior. As stated by one female student, her boyfriend often asked her to see sexual scenes stored on his phone, and did it (sexual intercourse) after seeing the scene. "I can't refuse ...." she said.

\section{There is no Legal Protection Regarding Dating Violence}

The absence of legal protection regarding dating violence, resulting in the absence of access to justice for victims and dating violence is still rampant, even increasing.

Based on the explanation above, it can be argued that the root causes of violent behavior in dating are patriarchal culture and low understanding of gender, resulting in inequality of gender relations, gender-biased parenting styles, negative perspectives (stereotypes) towards women. This condition is coupled with the absence of understanding about dating violence, less than optimal personality development, peer influence, media influence and the absence of legal regulations regarding dating violence. These causes are interrelated with one another and become an inseparable unit building dating violence behavior in the student environment of Pekalongan.

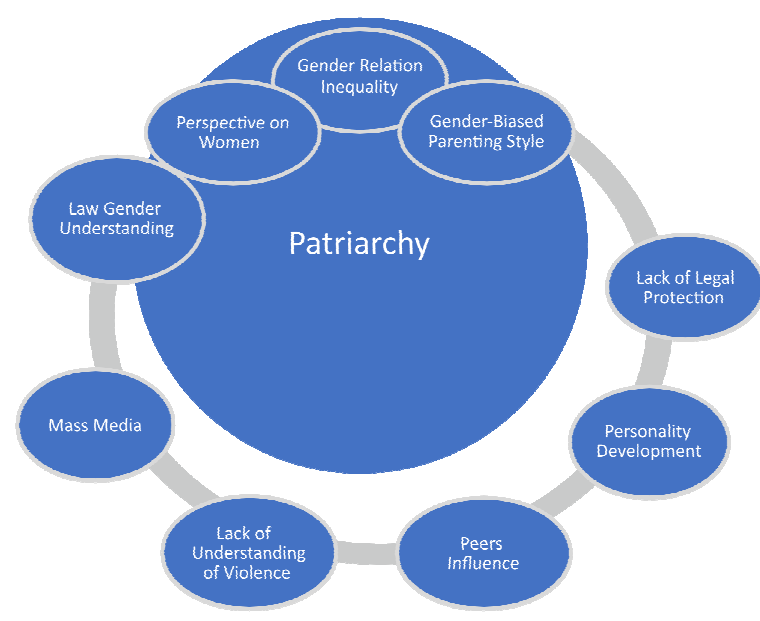

Figure I

Cause of Dating Violence 
This chart can be interpreted as, patriarchal culture has a big share of Dating violence behavior, which is reinforced by a low understanding of gender, thus creating a perspective on women and gender-biased parenting which leads to inequality of gender relations in dating relationships. This condition is exacerbated by the absence of an understanding of violence, including dating violence, less than optimal personality development, peer influence, media influence and the absence of legal protection on dating violence.

\section{Impact of Dating Violence}

Dating violence has an impact on both the victim and the perpetrator, especially the victims. The research results showed that the impact of violence in dating, namely: 1) impacts on the victims, including stress; low self-esteem; excessive anxiety; depression; decreased performance; limited space for the victim to move, because the perpetrator always supervised and prohibited them; loss of comfort and togetherness with family; eating disorders; experiencing physical pain; and pregnant out of wedlock, to life-threatening abortion; 2) impacts on the perpetrators, among others: enforcing the negative behavior in him because the usual violent behavior against a partner will continue over and over and over again, even though he has changed partners and; reinforcing negative perspectives on women (weak, helpless, stupid, easy to seduce, easy to deceive, gold digger and others).

These various impacts are interrelated and affect one another, forming a single result from the violence perpetrated against the victim.

\section{Access to Justice for Victims of Dating Violence}

According to Article 27 Verse (1) of the 1945 Constitution of the Republic of Indonesia, every citizen has the same position before the law (the principle of equality before the law). This means that the State, for whatever reason, should not discriminate against citizens, both men and women, because they have equal access to justice. According to Rhode, the principle of equality before the law is defined as equal access to the legal and justice system. ${ }^{43}$

Access to justice is a condition and process in which the State guarantees the fulfillment of basic rights for citizens based on the 1945 Constitution of the Republic of Indonesia and universal human rights principles. Guarantees access

\footnotetext{
${ }^{43}$ Deborah L Rhode, Access to Justice (Oxford University Press, 2004), 3.
} 
every citizen to know, understand, realize, and use their basic rights through formal and non-formal institutions, supported by an excellent and responsive public complaint handling mechanism to obtain optimal benefits and improve the quality of their own lives. ${ }^{44}$ The concept of access to justice is not limited to access to lawyers and courts, but also access to the Ombudsman and other "justice" institutions. ${ }^{45}$

Rankin distinguishes access to justice as a formal and substantive concept. The formal concept of access to justice is the ability of everyone to have adequate and effective access to courts and the opportunity to obtain quality legal services. Access to justice in this context focuses on conditions in court, namely: court procedures, court fees and the availability of lawyers. Substantive concepts focus more on a person's ability to obtain substantive justice. This means the ability of everyone to be able to access a more comprehensive legal system. $^{46}$

Based on this concept, access to justice for victims of dating violence behavior is interpreted as a condition in which victims receive legal protection while at the same time knowing, understanding, realizing and exercising their rights to obtain justice and legal certainty. It means that access to justice for victims of dating violence can only be obtained if, from the perspective of the legal structure, legal substance and legal culture are based on gender justice and are not discriminatory. ${ }^{47}$

In terms of legal substance, specific legal regulations governing the Elimination of Dating Violence do not yet exist. Still, if a case occurs, it can refer to statutory regulations, both material and formal, including Criminal Code (KUHP) ${ }^{48}$, Constitution Number 8 of 1981 concerning Criminal Procedure Law, Constitution of the Republic of Indonesia Number 31 of 2014 concerning

\footnotetext{
${ }^{44}$ Strategi Nasional Akses pada Keadilan 2016-2019 (Jakarta: Kementerian Perencanaan Pembangunan Nasional BAPPENAS RI, 2019), 2.

${ }^{45}$ Agus Raharjo, A Angkasa, and Rahadi Wasi Bintoro, "Akses Keadilan bagi Rakyat Miskin (Dilema dalam Pemberian Bantuan Hukum oleh Advokat)," Mimbar Hukum 27, no. 3 (2015): 432444.

${ }^{46}$ Micah B Rankin, "Access to Justice and the Institutional Limits of Independent Courts," Windsor Yearbook of Access to Justice 30, no. 1 (2012): 101-38, https://doi.org/10.22329/ wyaj.v30i1.4362.

47Lawrence M. Friedman, Sistem Hukum (Bandung: Nusa Media, 2013), 19.

${ }^{48}$ Kitab Undang-Undang Hukum Pidana.
} 
amendments to Constitution Number 13 of 2006 concerning Protection of Witnesses and Victims. Regulation of the Supreme Court of the Republic of Indonesia Number 3 of 2017 concerning Guidelines for Adjudicating Women's Cases Against the Law. Constitution of the Republic of Indonesia Number 11 of 2012 concerning the Criminal Justice System for Children; and then of the Republic of Indonesia No. 35 of 2014 concerning Amendments to Number 23 of 2002 concerning Child Protection, if the victim is under 18 years of age. Regulation of the Head of the National Police of the Republic of Indonesia Number 10 of 2007 concerning the Organization and Work Procedure of the Women and Children Service Units (UPPA) within the Republic of Indonesia National Police; Regulation of the State Minister for Women's Empowerment and Child Protection Number 1 of 2010 concerning Minimum Service Standards for Integrated Services for Women and Children Victims of Violence; and Regulation of the State Minister for Women's Empowerment and Child Protection Number 9 of 2011 concerning Guidelines for Empowering Women Victims of Violence.

Substantially, the Criminal Code as material law does not yet recognize gender-based violence and articles on sexual violence are categorized as crimes of morality. Constitution Number 8 of 1981 concerning Criminal Procedure Law, KUHAP as formal law also has not yet regulated women's rights as victims of violence or as perpetrators. Constitution of the Republic of Indonesia Number 31 of 2014 concerning amendments to Constitution Number 13 of 2006 concerning Protection of Witnesses and Victims, as a supporter of the Criminal Code also does not accommodate the interests of women who conflict with the law.

Other laws and regulations pay attention to women victims of violence, which can also be used as guidelines for victims of dating violence, namely: Regulation of the Supreme Court of the Republic of Indonesia Number 3 of 2017 concerning Guidelines for Adjudicating Cases of Women Facing the Law; Regulation of the Head of the National Police of the Republic of Indonesia Number 10 of 2007 concerning the Organization and Work Procedure of the Women and Children Service Units (PPA Unit) within the Republic of Indonesia National Police; Regulation of the State Minister for Women's Empowerment and Child Protection Number 1 of 2010 concerning Minimum Service Standards for Integrated Services for Women and Children Victims of Violence; 
Regulation of the State Minister for Women's Empowerment and Child Protection Number 9 of 2011 concerning Guidelines for Empowering Women Victims of Violence. However, these regulations have no legal force because they are limited to Supreme Court regulations and Ministerial regulations. The lack of strength and legal protection for dating violence victims means that victims do not have access to justice which should be their right.

In terms of the legal structure, namely law enforcement officials and agencies that do not yet have gender sensitivity, it will become an obstacle for victims to access justice. According to Khusnaeny, et al, there are several things that hinder or become obstacles for women victims of violence to get access to justice, from the perspective of law enforcers, namely: 1) Interpretation of the substance of criminal procedural law which is still gender-biased. 2) Attitudes of law enforcers towards victims are influenced by patriarchal culture, thus blaming the victims, who in fact are women. 3) The approach used by law enforcers is formal juridical (positivistic). 4) The subsystem in the Criminal Justice System is only limited to the Police, Attorney General's Office, Courts and Correctional Institutions, even though it should be in handling dating violence cases, apart from legal advisors there are also other parties as subsystems in the Criminal Justice System, namely service providers that provide assistance to women victims of violence, service provider institutions that provide psychological assistance and/or health services, and service provider institutions that provide protection for victims, both in the form of temporary housing (shelter) and safe houses. ${ }^{49}$

In terms of legal culture, namely, the community's ideas, values, and mindset, including the victims, regarding cases of violence against women in dating violence, are still gender-biased and patriarchal. It means that if a dating violence case occurs, then the ones who are blamed are the victims (blaming the victims) who are women, even the victims are silent because they feel embarrassed if they tell others. Phrases often made by the community when a dating violence case occurs, for example: "That's why you have to protect your dignity as women" or "Disgraceful, tarnishing the family's name" and others that

${ }^{49}$ Asmaul Khusnaeny and Ema Mukarrah, Membangun Akses ke Keadilan bagi Perempuan Korban Kekerasan: Perkembangan Konsep Sistem Peradilan Pidana Terpadu Penanganan Kasus Kekerasan terhadap Perempuan (SPPT-PKKTP) (Jakarta: Komisi Nasional Anti Kekerasan terhadap Perempuan - Komnas Perempuan, 2017), 29-30. 
cornered the victim. The legal culture of Law enforcement officials is also not much different from the general public in handling dating violence cases. This condition is certainly an obstacle for victims to gain access to justice. This is reinforced by the fact that society, including victims, does not yet have the knowledge, understanding, and awareness of using their rights to obtain justice.

Based on the results of the research, what caused the victim to not take action against dating violence behavior were: 1 ) very much in love with her boyfriend and afraid of being abandoned; 2) hopes that her boyfriend will change; 3) Feeling afraid and worried that the boyfriend will hurt or take revenge; 4) Feeling guilty or ashamed; 5) there is no other alternative; 6) do not know, understand and realize that they can ask for help from competent parties. For example, LBH and others; 7 lack of support both socially and individually; 8) assume that it's better rather than not having a boyfriend; 9) violence by boyfriend is considered natural and; 10) believe that violence committed by boyfriend will disappear after marriage or having children. ${ }^{50}$ The dating violence case that entered LBH of the Faculty of Sharia of IAIN Pekalongan, in 2019, namely: the case of a student who received threats through WhatsApp from her boyfriend that he will spread her sensual photos on social media. The victim said that if she had been dating for four years and her boyfriend ordered her to send a photo using only a bra as a form of consolation because he misses her when they're not together. Her boyfriend was a very jealous person, and if they fight, he always threatens to spread the photos to the lecturers and other students. "All this time I was silent because I loved him, but as time passes I felt uncomfortable and depressed. I am confused and ashamed, don't know who to tell, especially to my parents, they will be angry and blame me". The meaning of the word "silent"; "loved"; "confused and ashamed" dan "afraid to be blamed" is the embodiment of the values constructed by a patriarchal society.

Socio-cultural aspects based on patriarchy that instill differences between men and women, where a man is required to have a masculine image, while women are attached to a feminine image so that men are considered normal if they are aggressive, while women are expected to curb their aggressiveness. The facts show that victims who are women tend to be weak, lack selfconfidence, and love their boyfriend very much, especially if the boyfriend, after

50Private interview on 21 July to 30 August 2019. 
committing violence usually shows an attitude of regret, apologizes, promises never to do it again, and acts sweet, resulting in repeated circles endless violence. This condition is also an obstacle for victims to gain access to justice.

\section{Conclusion}

Forms of dating violence, namely: verbal-emotional, physical, sexual, and economic violence. The causes of dating violence behavior, namely: patriarchal culture; low understanding of gender; inequality of gender relations; gender bias parenting; negative perspective on women; less than optimal personality development; peer influence; media influence and the absence of specific legal regulations regarding dating violence. The impact of dating violence on victims, namely: stress; decreased self-confidence; increasing anxiety; feeling constantly depressed; decreased academic achievement; limited space for victims to move; lose the sense of comfort and togetherness with family; eating disorders; experiencing physical pain and; pregnancy out of wedlock, to a life-threatening abortion. The impact on the perpetrators, namely: to strengthen negative behavior in him, and; reinforce the negative perspective on women.

The victims of dating violence have not had access to justice, because: 1) in terms of legal substance, there are no specific rules regarding dating violence, while existing laws and regulations are gender-biased, even other regulations that can accommodate victims are only in the form of Supreme Court Regulations and Ministerial Regulation; 2) in terms of legal structure, law enforcement officials are low on gender sensitivity, so that if a dating violence case occurs they tend to blame the victim; 3) a legal culture based on patriarchy makes the community, as well as, victims consider that dating violence is a private domain and is considered "natural" because it is dynamic in the relationship. This condition is confirmed by the fact that the community, including victims, does not yet have the knowledge, understanding, and awareness of using their rights to obtain justice.

Efforts to strengthen understanding of gender and dating violence, their forms and impacts on students, including socialization regarding access to law and justice for the victims of dating violence in various student activity unit forums or other forums both on-campus and off-campus are things that must be done immediately. The formation of special regulations regarding the elimination of dating violence in the future (ius constituendum) must also be used as the political agenda of the government and legislators. 


\section{Acknowledgment}

Thanks to the Legal Aid Institute Team of the Faculty of Sharia of IAIN Pekalongan and students who have helped find information and data to complete this research. To all parties concerned, thank you

Then, this will lead us to believe that it is the researcher's responsibility to locate the accurate information, do the necessary clarification and confirmation and act ethically to analyze and synthesize the available resources to reach real and true knowledge.[s]

\section{References}

Adhi N., Wisnu. "Kekerasan terhadap Perempuan di Jateng Masih Tinggi." Antara News, April 21, 2017. https://www.antaranews.com/berita/625333/ kekerasan-terhadap-perempuan-di-jateng-masih-tinggi.

Ariel, Yatdianto. "Kekerasan dalam Pacaran Ditinjau dari Prasangka Gender." UNIKA Soegijapranata, Semarang, 2015.

Arivia, Gadis. Filsafat BerperspektifFeminis. Jakarta: Yayasan Jurnal Perempuan, 2003.

Azmiani, Azmiani, and Ratna Supradewi. "Hubungan Sikap Laki-Laki terhadap Kesetaraan Gender dengan Kekerasan dalam Pacaran." Jurnal Psikologi Proyeksi 10, no. 1 (2015): 49-60. https://doi.org/10.30659/jp.10.1.49-60.

Bates, Thomas R. "Gramsci and the Theory of Hegemony." Journal of the History of Ideas 36, no. 2 (April 1975): 351-66. https://doi.org/10.2307/2708933.

Boeree, C. George. Personality Theories: Melacak Kepribadian Anda Bersama Psikolog Dunia. Edited by Abdul Qodir Shaleh. Translated by Inyiak Ridwan Muzir. Yogyakarta: Prismasophie, 2017.

Brewer, Gayle, and Loren Abell. "Machiavellianism, Relationship Satisfaction, and Romantic Relationship Quality." Europe's Journal of Psychology 13, no. 3 (2017): 491-502. https://doi.org/10.5964/ejop.v13i3.1217.

Chodorow, Nancy. The Reproduction of Mothering: Psychoanalysis and the Sociology of Gender. Berkeley \& Los Angeles: University of California Press, 1978.

Friedman, Lawrence M. Sistem Hukum. Bandung: Nusa Media, 2013.

Huda, M. Nur. "Kekerasan Seksual pada Perempuan di Jateng Terhitung Tinggi." Tribun Jateng, April 21, 2017. https://jateng.tribunnews.com/2017/04/21/ kekerasan-seksual-pada-perempuan-di-jateng-terhitung-tinggi.

Khusnaeny, Asmaul, and Ema Mukarrah. Membangun Akses ke Keadilan bagi Perempuan Korban Kekerasan: Perkembangan Konsep Sistem Peradilan Pidana Terpadu Penanganan Kasus Kekerasan terhadap Perempuan (SPPT-PKKTP). 
Jakarta: Komisi Nasional Anti Kekerasan terhadap Perempuan - Komnas Perempuan, 2017.

Komnas Perempuan. “CATAHU 2019: Korban Bersuara, Data Berbicara, Sahkan RUU Penghapusan Kekerasan Seksual Sebagai Wujud Komitmen Negara. Catatan Kekerasan terhadap Perempuan Tahun 2018." Komnas Perempuan, 2019. https://komnasperempuan.go.id/catatan-tahunan-detail/catahu-2019-korbanbersuara-data-berbicara-sahkan-ruu-penghapusan-kekerasan-seksual-sebagaiwujud-komitmen-negara-catatan-kekerasan-terhadap-perempuan-tahun-2018.

- "Lembar Fakta dan Poin Kunci Catatan Tahunan Komnas Perempuan Tahun 2019." Komnas Perempuan, 2019. https://komnasperempuan.go.id/catatantahunan-detail/lembar-fakta-dan-poin-kunci-catatan-tahunan-komnasperempuan-tahun-2019.

- _- "Siaran Pers Catatan Tahunan (CATAHU) Komnas Perempuan 2019: Hentikan Impunitas Pelaku Kekerasan Seksual dan Wujudkan Pemulihan yang Komprehensif bagi Korban." Komnas Perempuan, 2019. https:// komnasperempuan.go.id/siaran-pers-detail/siaran-pers-catatan-tahunancatahu-komnas-perempuan-2019.

Krahe, B. Perilaku Agresif. Yogyakarta: Pustaka Pelajar, 2005.

Lavoie, Francine, Line Robitaille, and Martine Hébert. "Teen Dating Relationships and Aggression." Violence Against Women 6, no. 1 (2000): 6-36. https://doi.org/ 10.1177/10778010022181688.

LBH Fakultas Syariah IAIN Pekalongan. “Laporan Hasil Survey," 2018.

Mansour, Fakih. Analisis Gender dan Transformasi Sosial. 10th ed. Yogyakarta: Pustaka Pelajar, 2013.

Mouffe, Chantal. "Hegemony and Ideology in Gramsci." In Gramsci and Marxist Theory (RLE: Gramsci). London: Routledge, 2014.

Putri, Annora Mentari, and Agus Santoso. "Persepsi Orang Tua tentang Kekerasan Verbal pada Anak." Jurnal Keperawatan Diponegoro 1, no. 1 (2012): 22-29.

Raharjo, Agus, A Angkasa, and Rahadi Wasi Bintoro. "Akses Keadilan bagi Rakyat Miskin (Dilema dalam Pemberian Bantuan Hukum oleh Advokat)." Mimbar Hukum 27, no. 3 (2015): 432-444.

Rankin, Micah B. "Access to Justice and the Institutional Limits of Independent Courts." Windsor Yearbook of Access to Justice 30, no. 1 (2012): 101-38. https://doi.org/ 10.22329/wyaj.v30i1.4362.

Rhode, Deborah L. Access to Justice. Oxford University Press, 2004.

Shinta, Dewita Hayu, and Oetari Cintya Bramanti. Kekerasan dalam Rumah Tangga: Reduksi Bentuk-Bentuk Kekerasan dalam Rumah Tangga dalam RUU KUHP. Edited by Erasmus Cahyadi. Jakarta: LBH APIK dan Aliansi Nasional Reformasi KUHP, 2007. 
Strategi Nasional Akses pada Keadilan 2016-2019. Jakarta: Kementerian Perencanaan Pembangunan Nasional BAPPENAS RI, 2019.

Straus, Murray A. "Prevalence of Violence Against Dating Partners by Male and Female University Students Worldwide." Violence Against Women 10, no. 7 (2004): 790811. https://doi.org/10.1177/1077801204265552.

Suryabrata, Sumadi. Psikologi Kepribadian. Jakarta: RajaGrafindo Persada, 2012.

Tong, Rosemarie Putnam. Feminist Thought: Pengantar Paling Komprehensif kepada Arus Utama Pemikiran Feminis. Yogayakarta: Jalasutra, 1998.

Utami, Winda Rizwanti. "Hubungan Antara Harga Diri dengan Perilaku Kekerasan dalam Pacaran." Universitas Muhammadiyah Malang, 2016.

Walgito, Bimo. Psikologi Umum. Yogyakarta: Andi Offset, 2003.

Wardani, Dyah Prita, and Yossy Setyanawati. "Tinjauan Viktimologi dan Perlindungan Hukum Korban Kekerasan dalam Pacaran." Serambi Hukum 8, no. 2 (2015).

Wollstonecraft, Mary. "Feminisme Liberal." In Feminist Thought: Pengantar Paling Komprehensif Kepada Aliran Utama Pemikiran Feminis, edited by Rosemarie Putnam Tong. Yogyakarta: Jalasutra, 1998.

Wulandari, Pingky. "Hubungan Antara Maskulinitas dengan Kekerasan dalam Pacaran pada Remaja Laki-Laki.” Universitas Mercu Buana Yogyakarta, 2019. 
The page has been intentionally left blank. 